\title{
Analysis of Students' Perceptions of Online Learning Media During the Covid-19 Pandemic (Study of E-learning Media: Zoom, Google Meet, Google Classroom, and LMS)
}

DOI: https://doi.org/10.47175/rissj.v2i1.177

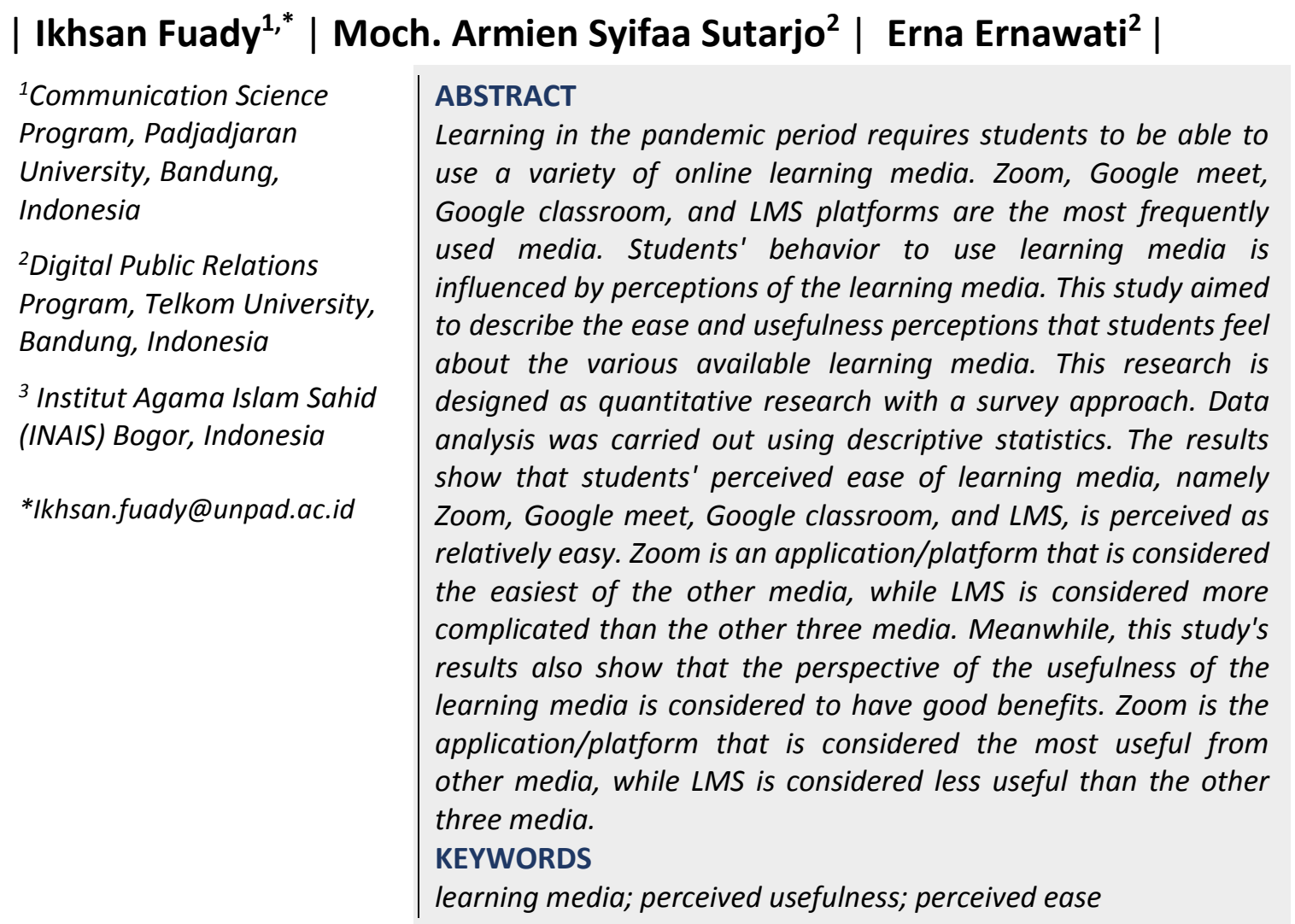

\section{INTRODUCTION}

Coronavirus is one of the primary pathogens that mainly serve the human respiratory system. Previous outbreaks of coronavirus $(\mathrm{CoV})$ have included severe acute respiratory syndrome (SARS). The Covid-19 disease outbreak that originated in Wuhan China has spread very rapidly throughout the world. The outbreak that was detected in December 2019 has caused many victims around the world.

In Indonesia, the latest conditions for the spread of the Covid-19 virus have caused concern for all parties. One of the efforts to prevent the widespread transmission is by issuing some strict policies (Yunus \& Rezki, 2020). According to Nature, the spread of the 2019 coronavirus disease (COVID-19) becomes ineligible and has met the epidemiological criteria to be declared as a pandemic where it has infected more than 100,000 people in 100 countries. Therefore, a coordinated global response is urgently needed to prepare the health system to meet this unprecedented challenge.

This pandemic has impacted people's lives in the social, economic, and educational fields. One of the sectors affected is the education sector. Schools and universities have been closed in several countries where the people are infected with COVID-19. This policy was done to prevent the spread of Covid-19 from becoming more widespread (Hassan et al., 2020). To suppress the spread of the pandemic, the government issued a social 
distancing policy. This social distancing policy greatly affected the learning activities in higher education institutions. The learning process in higher education must be continued to meet the needs of the students.

The solution that can be offered today to the educators is through online learning. As one of the crucial components of higher education, educators must be able to facilitate students with lectures, delivery of materials, and even an assessment system. Online learning involves the use of technology, which is carried out by students in the process of transferring knowledge and working on student assignments. This online learning activity is very beneficial for students who interact online to improve their performance quality (Hassan et al., 2020).

The dominant feature of online learning is the ease and flexibility of the learning process (Bower et al., 2015). In online learning activities, various applications/platforms can be used effectively in applications, websites, social networks or learning management systems (LMS). The multiple platforms available are used to help facilitate the learning as material delivery, assessment, or merely collecting assignments. According to some experts, LMS effectively manages to learn since it has complete and easily accessible features (Gunawan \& Fathoroni, 2020).

In its implementation, distance learning using a variety of platforms, as a substitute for face-to-face, has several drawbacks. Learning with a distance system is not entirely fun and acceptable to students (Hassan et al., 2020). Many students have difficulty understanding the lecture material provided online. Apart from that, there are other factors, namely superficial IT mastery, unstable internet access due to students' interior environment and so on (Hassan et al., 2020). Understanding how students perceive the use of various media platforms is fascinating to study. Student interest in instructional media is strongly influenced by individual perceptions of the learning media itself. (Ashari et al., 2018; Cheng \& Cho, 2011; Davis, 1989; Raida \& Néji, 2013) Individual behaviour is influenced by perceptions of technology, namely acceptance of learning platform users is determined by two key factors, namely perceived usefulness and perceived ease of use. Based on the above background, this study's objectives are; analyzing students' perceptions of several learning media platforms commonly used by students.

\section{RESEARCH METHODS}

This research was designed as a quantitative study with a survey approach. Based on the study's general objectives, the researcher attempted to determine the factors that influence individual intentions in implementing health protocols. To achieve this goal, researchers designed a descriptive study. Explanatory research is survey research that aims to describe the research variables descriptively (Earl Babbie, 2013).

This research was conducted on Padjadjaran University and Telkom University, West Java, in December 2020. This study's population was active students on the campus of Padjadjaran University and Telkom University, West Java, totalling 43,755. The sampling technique in this study used convenience sampling. Determination of the number of views used surveysistem.com with an alpha level of $10 \%$, the number of samples taken was 96 respondents. Data analysis in this study used descriptive statistics to describe the distribution of students' perceptions and intentions of learning media.

\section{RESULTS AND DISCUSSION}

Perception is an expedition of samples of objects by individuals. Davis (1989) revealed that individual behavior intentions could be understood by the perceptions of technology, 
namely acceptance of learning platform users that is determined by two key factors; they are perceived usefulness and perceived ease of use.

The pandemic learning process in the future, both in lectures and group discussions with students, must be done online. This condition causes learning activities to require representative media/platforms. At Padjadjaran University and Telkom University, learning activities combine several learning media platforms in improving the optimization of learning performance.

\section{Perceived ease of use of learning media}

This study aims to analyze the students' learning media perceived ease of use, which are most often used in Padjadjaran University and Telkom University, namely, zoom, Google meet, Google classroom, and LMS. Davis (1989) defines perceived ease of use as "the extent to which a person believes that using a particular system will be effortless and suggests that perceived ease of use has a positive effect on perceived usefulness". It has been supported by several studies. Abdullah et al. (2016) found a very significant positive relationship between students' perceived ease of use of technology and the perceived benefits. Based on the results of the study, students' perceptions of the learning media are described in the following table:

Table 1. Mean and standard deviation of the easiness perception of learning media

\begin{tabular}{lllll}
\hline Variables & Learning Platforms & Mean & SD & Category \\
\hline Perceived ease & Zoom & 3,6 & 0,54 & Very easy \\
& Google meet & 3,2 & 0,63 & Easy \\
& Classroom & 3,2 & 0,64 & Easy \\
& LMS & 2,9 & 0,70 & Difficult \\
\cline { 2 - 4 } & Mean & 3,2 & 0,63 & \\
\hline
\end{tabular}

Source: research data analysis

Based on table 1 above, all learning media's perceived ease on average is perceived as easy. According to the students, the learning platform that was perceived as the easiest was Zoom platform, while LMS was a quite tricky platform. Zoom is perceived as a learning platform that is relatively easy. This platform has relatively familiar and straightforward features. Meanwhile, respondents viewed that LMS is a complex platform in its operation. The distribution of students' perceptions of this platform is illustrated in table 2 below:

Table 2. Distribution of the percentage of respondents based on the scale of the ease of learning media platforms

\begin{tabular}{llcccc}
\hline & Easiness Scale & $\begin{array}{c}\text { Zoom } \\
(\mathbf{\%})\end{array}$ & $\begin{array}{c}\text { Google meet } \\
(\%)\end{array}$ & $\begin{array}{r}\text { Google classroom } \\
(\%)\end{array}$ & $\begin{array}{r}\text { LMS } \\
(\%)\end{array}$ \\
\hline Easiness & Very easy & 63,2 & 36,5 & 37,9 & 17,9 \\
perception & Easy & 34 & 57,7 & 51,6 & 58,9 \\
& Difficult & 2,8 & 3,8 & 10,5 & 20,0 \\
& Very difficult & 0 & 1,9 & 0 & 3,2 \\
\hline
\end{tabular}

Source: research data analysis

Table 2 shows that, in general, most students perceived all platforms as easy learning media. It appears that more than 80 percent of respondents rated it easy and very easy. Only the LMS media was considered easy and very easy with 76 percent. Meanwhile, 23.2 percent of the respondents also rated LMS as difficult and very difficult. This data shows that LMS is a relatively more difficult for than the other four platforms. 


\section{Perceived Usefulness of Learning Media}

According to Davis (1989), users' behavioral intention to adopt technology is determined by their perceptions of technology usability and ease of use (ÖZBEK et al., 2015). (Davis, 1989) defines perceived benefit as "the degree to which a person believes that using a particular system will improve his / her performance. Scholars have also stated that perceived usefulness has a positive influence on behavioral intention. This relationship is supported by various recent studies (Bhatiasevi \& Yoopetch, 2015).

Based on the results of the analysis, table 3 below shows the perception of the benefits of learning media:

Table 3. The mean and standard deviation of the perceived usefulness of learning media

\begin{tabular}{lllll}
\hline & & Mean & SD & Category \\
\hline Perceived & Zoom & 3,5 & 0,6 & Quite useful \\
usefulness & Google meet & 2,9 & 0,7 & Quite useful \\
& Google Classroom & 3,1 & 0,7 & Quite useful \\
& LMS & 2,9 & 0,7 & Quite useful \\
\cline { 2 - 4 } & Mean & 3,1 & 0,7 & \\
\hline
\end{tabular}

Source: research data analysis

Table 3 shows that the respondents' perceived usefulness towards all the platforms are quite useful, with an average score of 3.1. The learning media that are considered to have the highest usefulness are Zoom media, then Google classroom, while Google meet and LMS have lower perceptions of benefits with an average score of 2.9. The distribution of students' perceived usefulness of this learning platform is illustrated in table 4 below:

Table 4. The percentage distribution of respondents based on the scale of the usefulness of the learning media platforms.

\begin{tabular}{lllccl}
\hline & Usefulness Scale & Zoom & Google meet & Google classroon & LMS \\
\hline Perceived & Very useful & 61,5 & 19,2 & 33,3 & 25,5 \\
usefulness & Quite useful & 31,7 & 59,6 & 46,5 & 50,0 \\
& Less useful & 5,8 & 18,3 & 19,2 & 22,5 \\
& Unuseful & 1,0 & 2,9 & 1,0 & 2,1 \\
\cline { 2 - 6 } & Total & 100 & 100 & 100 & 100 \\
\hline
\end{tabular}

Source: research data analysis

Table 4 shows that, in general, most students perceived all learning media platforms are useful. It seems that more than 75 percent of the assessments are quite useful and very useful. This analysis also shows that respondents' evaluations and assessments of LMS learning media's usefulness are the lowest compared to the other three media. However, LMS appeared as the media that could be accessed easily and very easily with 76 percent. Meanwhile, 23.2 percent of the respondents also accessed LMS as a platform that was categorized as difficult and very difficult. This data shows that LMS is perceived as a media that is relatively more difficult than other media.

\section{Discussion}

Learning during a pandemic forces us to adapt to the use of various learning technologies. Individual behavior to use technology is influenced by perceptions of technology. The acceptance of learning platform users is determined by two key factors: perceived usefulness and perceived ease of use. Perception is a belief or assessment of an object. Davis (1989) states that perceived benefit is perceived, as "the extent to which a person believes that using a particular system will improve his performance". While the perceived 
ease of use is" the extent to which a person believes that a particular use will feel the ease of use.

Acceptance of learning technology is strongly influenced by students' perceived ease of learning media. Based on the analysis results, the students perceived Zoom platform as a very easy media. Zoom is considered easy because this platform has features on the main display that are simple and easy to operate. Learning media, which is specified, is relatively more difficult than other media is LMS media. LMS media is considered more complicated and has complexity and utilization. Besides, LMS is deemed less friendly because its use must use an account affiliated with the institution.

Apart from the perception of convenience, technology's use is also influenced by the perception of technology's perceived benefits. Perceptions of the benefits felt by students about the learning media used are relatively diverse. However, most students assessed that the perceived usefulness of learning media platforms such as Zoom, Google meet, Google classroom, and LMS was categorized as very good or considered very useful. Of the four media analyzed, the Zoom platform is also considered to have high benefits. Furthermore, Zoom is considered relatively able to replace face-to-face synchronous,. It made this media considered acceptable. Compared to Google Meet, the perceived usefulness is that Zoom is more comfortable to operate. Meanwhile, the learning media with the lowest usefulness is LMS.

\section{CONCLUSION}

Students' behavior in using learning media is influenced by the perceived usefulness, and perceived ease of use. Students' dominant media in learning activities, both lectures and group discussions are media with the Zoom, Google meet, Google classroom, and LMS. Students' perceptions of Zoom, Google meet, Google classroom, and LMS are relatively easy. Zoom application/platform is the easiest of other media, while LMS is considered more difficult than the other three media. More than 75 percent of respondents' assessment of these four media is categorized as easy and very easy. Meanwhile, this study's results indicate that the perspective of the usefulness of the learning media also has good benefits. Zoom is the most useful application/platform from other media, while LMS is considered less useful than the other three media.

\section{REFERENCES}

Abdullah, D., Jayaraman, K., \& Kamal, S. B. M. (2016). A Conceptual Model of Interactive Hotel Website: The Role of Perceived Website Interactivity and Customer Perceived Value Toward Website Revisit Intention. Procedia Economics and Finance, 37(16), 170-175. https://doi.org/10.1016/s2212-5671(16)30109-5

Ashari, Sharifuddin, J., Mohammed, Z., \& Terano, R. (2018). Paddy farmer's perception and factors influencing attitude and intention on adoption of organic rice farming. International Food Research Journal, 25(December), S135-S145.

Bhatiasevi, V., \& Yoopetch, C. (2015). The determinants of intention to use electronic booking among young users in Thailand. Journal of Hospitality and Tourism Management, 23, 1-11. https://doi.org/10.1016/j.jhtm.2014.12.004

Cheng, S., \& Cho, V. (2011). An integrated model of employees' behavioral intention toward innovative information and communication technologies in travel agencies. Journal of Hospitality and Tourism Research, 35(4), 488-510. https://doi.org/10.1177/1096348010384598

Davis, F. D. (1989). Perceived usefulness, perceived ease of use, and user acceptance of information technology. MIS Quarterly: Management Information Systems, 13(3), 319- 
339. https://doi.org/10.2307/249008

Earl Babbie. (2013). THE BASICS OF SOCIAL RESEARCH. In Вестник Казнму: Vol. №3.

Gunawan, N. M. Y. S., \& Fathoroni. (2020). Variations of Models and Learning Platforms for Prospective Teachers During the COVID-19 Pandemic Period. Indonesian Journal of Teacher Education, 1(2), 75-94.

Hassan, A., Tun, U., Onn, H., Ariffin, A., Tun, U., Onn, H., Ahmad, F., Tun, U., Onn, H., Hamzah, N., Tun, U., \& Onn, H. (2020). Students' Perceptions of Using Zoom Meet Webinar During COVID-19 STUDENTS' PERCEPTIONS OF USING ZOOM MEET WEBINAR DURING COVID-19 PANDEMIC IN. Journal Of Critical Reviews, November.

ÖZBEK, A. P. V., GÜNALAN, L. M., KOÇ, A. P. F., ŞAHINN, N. K., \& KAŞ, E. (2015). The Effects of Perceived Risk and Cost on Technology Acceptance: A Study on Tourists' Use of Online Booking. Celal Bayar Üniversitesi Sosyal Bilimler Dergisi, 13(2). https://doi.org/10.18026/cbusos.49782

Raida, R. E., \& Néji, B. (2013). The Adoption of the E-Banking: Validation of the Technology Acceptance Model. Technology and Investment, 04(03), 197-203. https://doi.org/10.4236/ti.2013.43023

Yunus, N. R., \& Rezki, A. (2020). Kebijakan Pemberlakuan Lock Down Sebagai Antisipasi Penyebaran Corona Virus Covid-19. SALAM: Jurnal Sosial Dan Budaya Syar-I, 7(3). https://doi.org/10.15408/sjsbs.v7i3.15083 